\title{
The Role of Antibodies to Steroid Hormones and Chemical Carcinogen Benzo[A]Pyrene in Preterm Prelabour Rupture of Membranes
}

\author{
Artymuk $\mathrm{NV}^{1 *}$, Elizarova $\mathrm{NN}^{1}$ and Polenok EG ${ }^{2}$ \\ ${ }^{1}$ Kemerovo State Medical University, Russia \\ ${ }^{2}$ Institute of Human Ecology of Federal Research Center of Coal and Coal chemistry of Siberian Branch of the Russian Academy of Sciences, Russia
}

Submission: December 07, 2017; Published: December 18, 2017

*Corresponding author: Natalia V Artymuk, MD, Professor, Head of the Department of Obstetrics and Gynecology № 2 of Kemerovo State Medical University, President of the "Obstetrians and Gynecologists' Association”, Kemerovo Region, Voroshilov Street, 22a, Kemerovo, Russia, 650029,

Tel: 73842396433; Fax: 73842734856; Email: roddom_kokb@mail.ru

\section{Abstract}

Background: Infants born too early are of public health concern since complications associated with preterm birth (PTB) are the leading cause of children's mortality and a major cause of morbidity and disability. Preterm prelabour rupture of membranes (PROM) occurs in $40 \%$ of all spontaneous preterm deliveries.

Objective: of this study was to determine antibodies of immunoglobulin (Ig) classes A and G to estradiol (E2), progesterone (Pg), benzo[a] pyrene (Bp) and their ratios in women with preterm PROM at $22^{+0}-36^{+6}$ weeks of gestation.

Methods: This article focuses on the relationship of antibodies to steroid hormones, chemical carcinogen -Bp and preterm PROM. During prospective, comparative, analytical study the blood serum for the presence of antibodies of Ig classes A and G to E2, Pg and Bp from 149 pregnant women was taken. Group I consisted of 68 women with PROM at $22^{+0}-36^{+6}$ weeks, group II-81 women without PROM at $22^{+0}-36^{+6}$ weeks of gestation.

Results: The increased level of antibodies to E2, the ratio of IgA-Bp/IgA-Pg; IgA-E2/IgA-Pg and IgG-Bp/IgG-Pg was identified in women with PROM at $22^{+0}-36^{+6}$ weeks of gestation.

Conclusion: Determination of antibodies and their relationship to estradiol, progesterone and benzo[a]pyrene probably can also be used to predict prelabour rupture of membranes in preterm period.

Keywords: PROM; PTB; Antibodies; Benzo[a]pyrene; Estradiol; Progesterone

Abbrevations: Bp: Benzo[a]pyrene; BSA: Bovine serum albumin; EDCs: Endocrine disrupting chemicals; E2: Estradiol; ELISA: Enzyme-linked immunosorbent assay; Ig: Immunoglobulin; Pg: progesterone; PROM: Prelabour rupture of membranes; PTB: Preterm birth

\section{Introduction}

Infants born too early are of public health concern since complications associated with preterm birth (PTB) are the leading cause of children's mortality and a major cause of morbidity and disability [1,2]. Preterm prelabour rupture of membranes (PROM) occurs in $40 \%$ of all spontaneous preterm deliveries. [3-6]. The proportion of PTB has no tendency to decrease and remains at the level of 5-10\% varying from region to region in different countries. In recent years it has increased as the result of new reproductive technologies [7].

The question about the pathogenesis of preterm PROM in pregnancy is considered from different angles. However, the contribution of both endogenous and exogenous autoimmune mechanisms is not sufficiently studied. The violation of the autoimmune tolerance to own tissues can lead to a number of problems of reproduction including complications during pregnancy, PTB, recurrent miscarriage, infertility and malformations in the fetus [8]. According to some studies a link between the presence of antibodies to sex hormones and reproductive dysfunction was discovered. As for medical scientific literature, a strong increase of antibodies to steroid hormones results in adverse pregnancy outcomes [9,10].

It is assumed that the formation of antibodies to endogenous steroids is linked with specific immune reactions to xenobiotics in the environment [11]. Benzo[a]pyrene (Bp), the most common of the studied exogenous xenobiotics, belongs to the class of polycyclic aromatic hydrocarbons. It is the primary mutagen in tobacco smoke and a very strong transplacental carcinogen [12]. Bp belongs to the group of endocrine disrupting chemicals 
(EDCs) due to the presence of hormone-like properties. Effects of EDCs may be transmitted to further generations through epigenetic modifications or from continued exposure of offspring to the environmental insult.

EDCs are inferior to the activity of endogenous sex steroids. However, prolonged exposure or in conjunction with other xenobiotics, EDCs can cause disorders of the endocrine function of the body by binding with receptors of sex steroids, most commonly with estrogen receptors, showing both a stimulating and a blocking effect [13].

\section{Materials and Methods}

The aim of this study was to determine antibodies of Ig classes $\mathrm{A}$ and $\mathrm{G}$ to $\mathrm{E} 2, \mathrm{Pg}, \mathrm{Bp}$ and their ratios in women with preterm PROM at $22^{+0}-36^{+6}$ weeks of gestation.

We used a prospective, comparative, analytical study design approved by the Ethics Committee of Kemerovo State Medical University. In our study 149 pregnant women of reproductive age were assessed to be eligible and recruited for the study.

The criteria for inclusion in group I: preterm pregnancy $\left(22^{+0}-36^{+6}\right.$ weeks) complicated by premature PROM. Exclusion criteria in group I: term pregnancy (37 weeks or more), timely discharge of amniotic fluid. The criteria for inclusion in group II: term pregnancy, term delivery, timely discharge of amniotic fluid. Criteria for exclusion in group II: preterm delivery $(22+0-$ $36+6$ weeks), premature PROM, early rupture of membranes or amniotomy.

Group I consisted of 68 women with preterm PROM at $22^{+0}$ $36^{+6}$ weeks, group II - 81 women without preterm PROM at $22^{+0}$ $36^{+6}$ weeks of gestation.

Clinical history was obtained and physical examination was performed in all cases. Levels of Ig A and G to E2, Pg, Bp were determined using enzyme-linked immunosorbent assay (ELISA) with minor modifications, when membranes were ruptured in Group I and without preterm PROM in Group II [14]. All results were measured with the platereade Multiscan FC (Finland). The levels of antibodies were expressed in units (IU/l) and calculated from the ratio of antibodies binding to the conjugated with bovine serum albumin (BSA, Amresco, USA) (minus background binding with BSA) to BSA.

The Statistical Package, Statistica v.6.0, was used for the analysis. A p-value of less than 0,05 was considered statistically significant.

\section{Results}

Based on the data, it was evident that the level of Ig A to E2 was considerably higher in women of group I than of group II $(p=0,002)$. Antibody levels are shown in Table 1.

The level of Ig A to Pg was much higher in women of group II, but any statistically significant differences were not found out $(p=0,766)$. The level of Ig A to Bp was equal to $4,4 \mathrm{IU} / \mathrm{l}$ and 3,8
IU $/ \mathrm{l}$ in groups respectively $(\mathrm{p}=0,188)$. The median ratios of Ig $\mathrm{A}$ to $\mathrm{Bg} / \mathrm{Pg}(\mathrm{p}=0,040)$, Ig A to $\mathrm{E} 2 / \mathrm{Pg}(\mathrm{p}<0,001)$ were statistically considerably higher in women in group I compared with group II. The median ratios of Ig A Bp/E2 didn't differ much between two groups.

Table 1: Levels of antibodies to $\mathrm{Es}, \mathrm{Pg}, \mathrm{Bp}$ in women of group I and group II.

\begin{tabular}{|c|c|c|c|}
\hline \multirow{2}{*}{$\begin{array}{c}\text { Levels of } \\
\text { Antibodies }\end{array}$} & Group I(n=68) & $\begin{array}{c}\text { Group II } \\
\text { (n=81) }\end{array}$ & \multirow{2}{*}{$\mathbf{p}$} \\
\cline { 2 - 3 } & Me & Me & \\
\hline Ig A E2, IU/l & 5,6 & 4 & 0,002 \\
\hline Ig A Pg, IU/l & 2,9 & 3,1 & 0,766 \\
\hline Ig A Bp, IU/l & 4,4 & 3,8 & 0,188 \\
\hline Ig A Bp/E2 & 0,8 & 0,9 & 0,241 \\
\hline Ig A Bp/Pg & 1,4 & 1,1 & 0,040 \\
\hline Ig A E2/Pg & 1,7 & 1,3 & $<0,001$ \\
\hline Ig G E2, IU/I & 8,6 & 9,8 & 0,511 \\
\hline Ig G Pg, IU/l & 5,6 & 5,3 & 0,986 \\
\hline Ig G Bp, IU/l & 7,9 & 7,3 & 0,219 \\
\hline Ig G Bp/E2 & 0,9 & 0,8 & 0,389 \\
\hline Ig G Bp/Pg & 1,6 & 1,3 & 0,018 \\
\hline Ig G E2/Pg & 1,6 & 1,4 & 0,052 \\
\hline
\end{tabular}

The number of Ig G to E2 in women of group I was lower than in group II, but there weren't any statistically significant differences $(p=0,511)$. The Ig $G$ to Pg didn't statistically differ much in both groups $(p=0,986)$. The same refers to the level of Ig $\mathrm{G}$ to $\mathrm{Bp}$ in women from both groups $(\mathrm{p}=0,219)$.

It was released that the ratio of Ig G to $\mathrm{Bp} / \mathrm{Pg}(\mathrm{p}=0,018)$ was statistically much higher in women of group I compared with group II. The median ratio of Ig $\mathrm{G}$ to $\mathrm{Bp} / \mathrm{E} 2$ in both groups was practically equal $(p=0,389)$. The median ratio of Ig G to $E 2 / P g$ was much higher in women of group I $(1,6)$ in comparison with group II $(1,4)$ but without any statistically significant differences $(\mathrm{p}=0,052)$.

\section{Discussion}

In this study the increased levels of antibodies Ig A to E2 were recorded in women with preterm PROM, the level of Ig to Pg didn't increase. According to Itsekson's [9], the increased levels of antibodies to Pg could be associated with pregnancy loss in women with premenstrual syndrome and dermatitis [9]. As for Gladkova's [15], antibodies to Pg were identified in almost half of women with recurrent reproductive loss this is one of the factors that causes recurrent miscarriage [15].

Menzhinskaya et al. [16] reported, that antibodies against gonadotropins and female sex hormones are considered as possible risk factors for infertility, in vitro fertilization failure and pregnancy loss [16].

In this study the increased levels of antibodies ratio of $\operatorname{IgA}$ $\mathrm{Bp} / \operatorname{IgA} \mathrm{Pg}$, IgA E2/ IgA Pg and IgG Bp/IgG-Pg were recorded 
in women with preterm PROM, therefore we can confirm the assumption of the unity of the mechanisms of antibody formation to EDCs and endogenous steroid hormones.

\section{Conclusion}

Thus, in women with premature rupture of membranes at $22^{+0}-36^{+6}$ weeks of gestation the increased levels of antibodies IgA to estradiol, the ratio of IgA benzo[a]pyrene/IgA progesterone, IgA estradiol/ IgA progesterone and IgG benzo[a]pyrene/ IgG-progesterone were recorded. Determination of antibodies and their relationship to estradiol, progesterone and benzo[a] pyrene probably can also be used to predict prelabour rupture of membranes in preterm period.

\section{References}

1. Bustos ML, Caritis SN, Jablonski KA, Reddy UM, Sorokin Y, et al. (2017) The association between cytochrome $\mathrm{P} 450$ 3A, progesterone receptor polymorphisms, plasma 17-OHPC concentrations, and spontaneous preterm birth. Am J Obstet Gynecol 217(3): 369.

2. Newnham JP, Kemp MW, White SW, Arrese CA, Hart RJ, et al. (2017) Applying precision public health to prevent preterm birth. Front Public Health 5: 66.

3. Chang HH, Larson J, Blencowe H, Spong CY, Simpson JL, et al. (2013) Preterm births in countries with a very high human development index - authors' reply. Lancet 381(9875): 1356-1357.

4. Blencowe $\mathrm{H}$, Cousens $\mathrm{S}$, Oestergaard MZ, Chou D, Moller AB, et al (2012) National, regional, and worldwide estimates of preterm birth rates in the year 2010 with time trends since 1990 for selected countries: a systematic analysis and implications. Lancet 379(9832): 2162-2172.

5. Liu L, Oza S, Hogan D, Perin J, Rudan I, et al. (2015) Global, regional, and national causes of child mortality in 2000-13, with projections to inform post-2015 priorities: an updated systematic analysis. Lancet 385(9966): 430-440.
6. Romero R, Miranda J, Chaemsaithong P, Chaiworapongsa T, Kusanovic $\mathrm{JP}$, et al. (2015) Sterile and microbial-associated intra-amniotic inflammation in preterm prelabor rupture of membranes. J Matern Fetal Neonatal Med 28 (12): 1394-1409.

7. Bohîlțea RE, Munteanu O, Turcan N, Baros A, Bodean O, et al. (2016) A debate about ultrasound and anatomic aspects of the cervix in spontaneous preterm birth. J Med Life 9(4): 342-347.

8. Poletaev AB (2010) Physiological immunology (natural autoantibodies and problems of nanomedicine). Miklosh, Moskow, p. 218.

9. Itsekson AM, Soriano D, Zolti M, Seidman DS, Carp HJ (2013) Intradermal sex hormone desensitization for relief of premenstrual symptoms may improve the obstetric outcome of women with recurrent pregnancy loss. Gynecol Endocrinol 29(2): 169-172.

10.Itsekson AM, Seidman DS, Zolti M, Alesker M, Carp HJ (2011) Steroid hormone hypersensitivity: clinical presentation and management. Fertil Steril 95: 2571-2573.

11.Glushkov AN (2003) Immunological mechanisms of adaptation to the low-weight chemical compounds in ontogenesis. Medical Hypotheses 61(3): 405-411.

12.Crowell SR, Hanson-Drury S, Williams DE, Corley RA (2014) In vitro metabolism of benzo[a]pyrene and dibenzo[def,p]chrysene in rodent and human hepatic microsomes. Toxicol Lett 228(1): 48-55.

13. Kandarakis ED, Bourguignon JP, Giudice LC, Hauser R, Prins GS, et al. (2009) Endocrine-Disrupting Chemicals: An Endocrine Society Scientifc Statement. Endocr Rev 30(4): 293-342.

14. Glushkov AN, Polenok EG, Anosova TP, SavchenkoYaA, Bakanova ML et al.(2011) Serum antibodies to benzo[a]pyrene and chromosomal aberrations in lymphocytes peripheral blood at the workers of coal processing enterprise. Russ J Immunol 5(1): 39-44.

15. Gladkova KA (2013) The Role of sensitization to progesterone in habitual miscarriage. AG-info (2): 7-11.

16. Menzhinskaya IV, Vanko LV (2017) Association of antibodies against gonadotropins and female sex hormones with reproductive disorders. Obstetrics and gynecology 9: 20-27.

\section{Your next submission with Juniper Publishers will reach you the below assets}

- Quality Editorial service

- Swift Peer Review

- Reprints availability

- E-prints Service

- Manuscript Podcast for convenient understanding

- Global attainment for your research

- Manuscript accessibility in different formats ( Pdf, E-pub, Full Text, Audio)

- Unceasing customer service

Track the below URL for one-step submission https://juniperpublishers.com/online-submission.php 